\title{
PENGGUNAAN PERMAINAN MEMASANGKAN KARTU DALAM PEMBELAJARAN BAHASA ARAB DI SMA
}

\author{
Maspalah \\ SMAN 1 Cicurug Sukabumi \\ Korespondensi: Jl. Koramil Kec. Cicurug Kab. Sukabumi 43259 \\ Telp. (0266) 731350; Pos-el: maspalah@ gmail.com
}

\begin{abstract}
Abstrak
Penelitian ini bertujuan untuk (1) mendeskripsikan penerapan penggunaan Permainan Memasangkan Kartu dalam pembelajaran bahasa Arab, (2) memperoleh data tentang kontribusi permainan tersebut dalam meningkatkan aktivitas siswa dalam belajar, dan (3) memperoleh data tentang kontribusi penggunaan permainan tersebut terhadap peningkatan kemampuan siswa dalam memahami teks tertulis. Metode yang digunakan adalah Penelitian Tindakan Kelas yang dilaksanakan dalam dua siklus dengan subjek penelitian siswa Kelas X3 SMAN 1 Cicurug Kabupaten Sukabumi. Melalui penelitian ini diungkap langkah-langkah pembelajaran dengan penggunaan permainan tersebut, sikap dan perilaku siswa dalam belajar, serta hasil belajarnya.
\end{abstract}

Kata-kata kunci: Permainan memasangkan kartu, pembelajaran bahasa Arab

\begin{abstract}
This study aims to (1) describe the application of the use of the Card Pair Game in the Arabic learning, (2) obtain data on the contribution of the game in increasing student activity in learning, and (3) obtain data on the contribution of the use of such games to increase students' ability in understanding the written text. The method used was Classroom Action Research is conducted in two cycles with a subject of research students Class X-3 SMAN 1 Cicurug Sukabumi. Through this study revealed the learning steps with the use of the game, the attitude and behavior of students in learning, and learning outcomes.
\end{abstract}

Keywords: Card pair game, arabic learning

\section{PENDAHULUAN}

Bahasa Arab adalah salah satu mata pelajaran bahasa asing pilihan yang diajarkan di SMA. Pengajaran bahasa Arab di SMA menggunakan sistem terpadu berbasis topik dengan bahan pelajaran utamanya adalah teks mengenai topik tertentu. Dari bahan utama ini kemudian dilakukan kegiatan: (1) pemahaman kosakata, (2) pemahaman isi teks, (3) penguasaan bunyi bahasa melalui membaca nyaring, (4) percakapan dengan topik yang relevan, (5) latihan menulis, (6) dan (7) penguasaan tatabahasa yang terdapat dalam teks. 
Tujuan pembelajaran bahasa

Arab di SMA sebagaimana ditegaskan dalam Lampiran Permendiknas Nomor 22 Tahun 2006 tentang Standar Isi (2006:295) adalah agar peserta didik memiliki kemampuan dasar dalam keterampilan mendengarkan, berbicara, membaca, dan menulis untuk berkomunikasi secara sederhana.

Namun, kenyataan menunjukkan bahwa sebagian besar siswa masih kesulitan memahami teks tertulis berbahasa Arab. Ratarata hasil ulangan untuk Kompetensi Membaca masih di bawah Kriteria Ketuntasan Minimal (KKM). Untuk memperbaikinya agar dapat mencapai KKM, diperlukan remedial pembelajaran dan remedial tes yang tidak cukup hanya dengan satu kali perlakuan.

Rendahnya pemahaman siswa terhadap teks tulisan berbahasa Arab ini kemungkinan dipengaruhi oleh berbagai faktor, antara lain karena kegiatan pembelajarannya terlalu serius dan kaku yang tidak memasukkan unsur bermain di dalamnya, metode yang digunakan guru tidak menarik, serta kurang optimalnya penggunaan media pembelajaran.

Hal tersebut didasarkan pada kenyataan bahwa selama ini proses pembelajaran Bahasa Arab berlangsung dalam suasana yang membosankan. Siswa tampak pasif, kurang bergairah, dan tidak terlibat aktif dalam pembelajaran. Mereka sering kali hanya duduk dan mengikuti perintah guru dari awal sampai akhir.

Di sisi lain, guru belum bersungguh-sungguh mau berinovasi dalam menggunakan teknik dan media yang dapat meningkatkan kualitas pembelajaran. Guru belum optimal dalam memfasilitasi siswa untuk terlibat aktif pada proses pembelajaran. Guru biasanya menggunakan metode ceramah dan tata bahasa-terjemah tanpa variasi yang berpusat pada guru dan berpaku pada buku teks.

Dalam mengajarkan keterampilan membaca, guru biasanya memulai dengan mengucapkan kosakata, lalu siswa mengikuti ucapan guru. Kemudian guru bertanya kepada siswa makna kata tersebut. Jika siswa tidak ada yang tahu, guru menerjemahkan kosakata tersebut ke dalam Bahasa Indonesia. Proses pembelajaran yang kurang kreatif seperti ini terkesan dangkal dan kurang membekas dalam memori siswa. Mereka susah mengingat dan mudah lupa karena pembelajaran kurang menyenangkan.

Dari uraian di atas tampak bahwa akar masalah rendahnya keterampilan membaca siswa dalam pembelajaran Bahasa Arab adalah karena siswa kurang terlibat aktif dalam pembelajaran sebagai akibat guru yang tidak berinovasi dalam menyajikan media pembelajaran secara menyenangkan. Kondisi ini perlu segera mendapatkan penanganan serius agar masalahnya tidak berlarut-larut.

Agar ada peningkatan proses dan hasil belajar, guru harus melakukan pembaharuan dengan menyajikan pembelajaran inovatif. Menurut Suyatno (2009:6) pembelajaran inovatif adalah pembelajaran yang dikemas oleh guru yang merupakan wujud gagasan atau teknik yang dipandang baru agar mampu memfasilitasi siswa untuk memperoleh kemajuan dalam proses dan hasil belajar. 
Di antara bentuk inovasi pembelajaran Bahasa Arab yang dapat dilakukan adalah penggunaan permainan dalam kegiatan pembelajaran. Permainan dalam pembelajaran ini dapat menumbuhkan tanggung jawab, kerja sama, persaingan sehat, dan keterlibatan belajar. Salah satu jenis permainan yang diduga dapat melibatkan aktivitas seluruh siswa dalam pembelajaran adalah pertandingan antarkelompok untuk beradu cepat dan tepat memasangkan kartu gambar dan kartu kalimat dalam waktu yang ditentukan.

Agar ada peningkatan proses dan hasil belajar, guru harus melakukan pembaharuan dengan menyajikan pembelajaran inovatif. Menurut Suyatno (2009:6) pembelajaran inovatif adalah pembelajaran yang dikemas oleh guru yang merupakan wujud gagasan atau teknik yang dipandang baru agar mampu memfasilitasi siswa untuk memperoleh kemajuan dalam proses dan hasil belajar.

Di antara bentuk inovasi pembelajaran Bahasa Arab yang dapat dilakukan adalah penggunaan media pembelajaran berbentuk permainan.

Menurut Shiny (1983:268) permainan kebahasaan merupakan salah satu jenis media pembelajaran bahasa yang dapat digunakan dalam pembelajaran bahasa Arab nonpenutur asli yang dapat memberikan suasana menyenangkan dan akan meninggalkan kesan positif di hati siswa.

Sedangkan menurut Sudjana \& Rivai (1992:2) manfaat media pembelajaran adalah sebagai berikut:

a. Pembelajaran akan lebih menarik perhatian siswa sehingga

dapat menumbuhkan motivasi belajar.

b. Bahan pembelajaran akan lebih jelas maknanya sehingga dapat lebih dipahami oleh siswa.

c. Metode mengajar akan lebih bervariasi sehingga siswa tidak bosan.

d. Siswa dapat lebih banyak melakukan kegiatan belajar

Sebuah permainan pasti mengandung unsur kegembiraan atau kesenangan. Apabila permainan digunakan dalam pembelajaran unsur kegembiraan ini akan mendukung unsur keseriusan dalam belajar. Seperti diungkapkan Sadiman (2011:78) permainan mempunyai beberapa kelebihan yakni memungkinkan adanya partisipasi aktif dari siswa untuk belajar, menyenangkan untuk dilakukan, memberikan umpan balik langsung, dan lain-lain. Demikian juga jika permainan digunakan dalam pembelajaran bahasa Arab. Di dalamnya akan terkandung unsur kegembiraan sekaligus keseriusan berlatih menggunakan bahasa dan unsur bahasa. Hal ini sejalan dengan pernyataan yang dikemukakan oleh Mujib dan Rahmawati (2011:32) yaitu bahwa permainan kebahasaan adalah cara mempelajari bahasa melalui permainan untuk memperoleh kesenangan serta melatih keterampilan berbahasa dan unsur bahasa yang telah dipelajari.

Salah satu jenis permainan kebahasaan yang dapat melibatkan aktivitas seluruh siswa dalam pembelajaran adalah pertandingan antarkelompok untuk beradu cepat dan tepat memasangkan kartu gambar dan kartu kalimat dalam waktu yang ditentukan. Selama 
pertandingan berlangsung, kelompok yang tidak sedang bermain ditugaskan untuk menjadi juri dan membantu kelancaran jalannya pertandingan. Sesuai dengan aktivitas utama yang ada di dalamnya, permainan ini dinamakan Permainan Memasangkan Kartu.

Permainan Memasangkan Kartu terinspirasi oleh sebuah permainan edukasi untuk memudahkan pemahaman kosakata melalui gambar. Suyatno (2009:43) menamakan permainan untuk memudahkan ingatan siswa dalam menghafalkan kata-kata melalui pemahaman gambar ini dengan permainan "Bingo Kata". Penamaan yang sama juga dikemukakan oleh Mujib dan Rahmawati (2011:75). Baik Suyatno maupun Mujib menekankan aktivitas permainan ini pada guru yang yang menunjukkan gambar lalu siswa menunjuk, memilih atau menyebutkan kata yang mewakili gambar tersebut dengan bahasa target.

Untuk mengatasi masalah rendahnya kemampuan siswa dalam memahami teks tertulis, penulis melalukan Penelitian Tindakan Kelas yang berlangsung dalam dua siklus dengan menggunakan Permainan Memasangkan Kartu dalam pembelajaran bahasa Arab di Kelas X-3 SMAN 1 Cicurug Kabupaten Sukabumi pada Semester II Tahun Pelajaran 2012/2013 untuk memperoleh data tentang pelaksanaan permainan tersebut dalam pembelajaran, kontribusi penggunaan permainan tersebut dalam meningkatkan aktivitas siswa dalam belajar, dan untuk memperoleh data tentang kontribusinya terhadap peningkatan kemampuan siswa dalam memahami teks tertulis.
Berdasarkan pengamatan sebelum penelitian, mayoritas siswa kelas ini menunjukkan sikap pasif dan kurang motivasi dalam belajar Bahasa Arab. Rata-rata hasil belajar mereka masih di bawah KKM dan lebih rendah dibandingkan dengan rata-rata hasil belajar kelas lain. Data yang diperoleh dari hasil ulangan Kompetensi Membaca siswa Kelas X-3 pada Semester I Tahun Pelajaran 2012/2013 menunjukkan bahwa siswa yang mencapai KKM hanya berjumlah 10 dari 40 orang siswa atau $25 \%$, dengan rata-rata nilai murni seluruh siswa Kelas X-3 sebesar 51, sedangkan KKM-nya adalah 75 .

Permainan Memasangkan Kartu pada penelitian ini merupakan variasi dan hasil modifikasi dari permainan "Bingo Kata" yang dikemukakan kedua penulis tersebut. Tujuannya sama tetapi cara dan penekanannya yang berbeda. Permainan Memasangkan Kartu lebih menekankan pada aktivitas dan interaksi siswa dlam kelompok. Mereka tidak terbatas pada menentukan kata yang sesuai dengan gambar yang ditunjukkan oleh guru, melainkan diberi kebebasan untuk memilih sendiri kartu gambar yang sesuai dengan kartu kalimat yang tersedia secara cepat dan tepat dalam waktu yang dibatasi. Suasana persaingan dengan kelompok lain untuk untuk mendapatkan pasangan kartu sebanyak-banyaknya membuat mereka merasakan adanya tantangan, tetapi di sisi lain dapat menimbulkan kesenangan sendiri bagi mereka.

Dalam permainan ini interaksi antarsiswa lebih banyak dan aktivitas mereka tidak monoton dengan hanya menebak makna gambar yang ditentukan urutannya oleh guru, tetapi dalam kelompoknya 
mereka diberi kebebasan untuk memilih sendiri kartu gambar yang sesuai dengan kartu kalimat yang tersedia secara cepat dan tepat dalam waktu yang dibatasi. Suasana persaingan dengan kelompok lain untuk mendapatkan pasangan kartu sebanyak-banyaknya membuat mereka merasakan adanya tantangan dan ketegangan tetapi di sisi lain dapat menimbulkan kesenangan tersendiri bagi mereka.

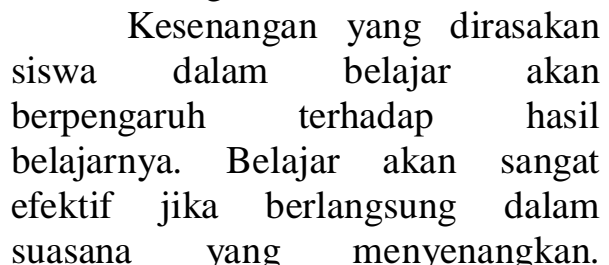
Konsep itulah yang menjadi landasan pentingnya melaksanakan pembelajaran yang menyenangkan. Pencetus kata-kata "Learning is most effective when it's fun" adalah Peter Kline, penulis buku The Everyday Genius sebagaimana diungkapkan oleh Hernowo (2005:15).

Efektivitas pembelajaran juga dipengaruhi oleh interaksi yang tercipta dalam proses pembelajaran. Penekanan interaksi dalam proses pembelajaran dianalogikan oleh konsep Quantum Teaching yang dikembangkan oleh Bobbi DePorter sebagai konsep Fisika. Menurut Yosodipuro (2013:137), konsep Quantum Teaching mengikuti konsep Fisika Quantum, yaitu:

$$
\begin{aligned}
& E=m c^{2} \\
& E=\text { Energi }
\end{aligned}
$$

efektivitas

(antusiasme, semangat)

$$
m=\text { massa (semua individu }
$$

yang terlibat, situasi, materi, fisik)

$$
c=\text { interaksi (hubungan yang }
$$

tercipta di kelas)

Menurut Hernowo (2005:17)

yang mengutip pendapat Dave Meier, penulis buku The Accelerated
Learnig Handbook, interaksi atau keterlibatan yang tercipta dalam proses pembelajaran itu merupakan salah satu komponen pembangun suasana yang menyenangkan. Menyenangkan atau suasana belajar dalam keadaan gembira ditandai dengan bangkitnya minat, adanya keterlibatan penuh, terciptanya makna, dan adanya pemahaman atau penguasaan materi.

Berdasarkan konsep yang dikemukakan oleh para ahli di atas dapat disimpulkan bahwa suasana yang menyenangkan dapat membuat pembelajaran menjadi lebih efektif, dan oleh karena itu maka guru hendaknya selalu berusaha untuk menyajikan pembelajaran yang menyenangkan bagi muridmuridnya.

\section{METODE}

Dalam penelitian ini, peneliti menggunakan metode penelitian tindakan kelas (PTK) atau classroom action research, yaitu:

"penelitian tindakan yang dilaksanakan oleh guru di dalam kelas, yang pada hakikatnya merupakan rangkaian tindakan-risettindakan-riset dan seterusnya, yang dilakukan secara siklik, dalam rangka memecahkan masalah, sampai masalah itu terpecahkan". (Supriyadi dalam Mulyadi, 2012: 12).

Konsep pokok action research menurut Kurt Lewin dalam Supriyadi (Mulyadi,2012:13) terdiri dari empat komponen, yaitu: (1) perencanaan (planning); (2) tindakan (acting); (3) pengamatan (observing), dan; (4) refleksi (reflecting). Hubungan keempat komponen itu dipandang sebagai satu siklus. 


\section{HASIL DAN PEMBAHASAN}

Pelaksanaan penelitian dilakukan secara kolaborasi dengan sesama guru bahasa Arab di sekolah peneliti yang membantu dalam pelaksanaan observasi dan refleksi selama penelitian. Secara umum, tahapan penelitian ini terdiri atas:

a. Perencanaan, meliputi penyiapan RPP, alat observasi, bahan ajar, media pembelajaran, dan alat evaluasi untuk Kompetensi Dasar Membaca Pemahaman yakni memperoleh berbagai informasi dari wacana tulis sederhana secara tepat.

b. Tindakan, meliputi seluruh proses pembelajaran yang di dalamnya terdapat penggunaan Permainan Memasangkan Kartu.

c. Observasi, dilaksanakan bersamaan dengan proses pembelajaran meliputi: aktivitas guru dan siswa, sikap siswa, dan hasil belajar siswa.

d. Refleksi, dilakukan dengan menganalisa kegiatan pembelajaran dan dilanjutkan dengan menyusun rencana perbaikan pada siklus berikutnya.

Pembelajaran pada Siklus 1 merupakan perbaikan dari hasil refleksi terhadap proses pembelajaran sehari-hari setelah diketahui motivasi dan hasil belajar mereka belum optimal. Kompetensi yang akan dicapai adalah memahami wacana sederhana bahasa Arab dengan topik Di dalam Kelas ()في (الفصل) yang mengandung struktur Kata Sifat.
Langkah-langkah

pembelajaran yang dilakukan berpedoman pada RPP yang telah disusun pada fase perencanaan. Tindakan yang dilakukan oleh peneliti dan sikap serta perilaku siswa diamati oleh observer dengan mengisi lembar pengamatan yang telah disiapkan.

Setelah penyajian materi oleh peneliti, permainan pun dilakukan. Para siswa tampak antusias dan penasaran dengan permainan yang akan dilaksanakan. Setelah menyampaikan aturan permainan, peneliti membagi siswa ke dalam 8 kelompok untuk 4 grup, mengatur tempat, membagikan kartu, dan mengatur jalannya pertandingan. Sementara itu observer memantau jalannya pertandingan.

Setelah permainan dilakukan, soal tes dibagikan kepada setiap siswa untuk mengetahui pemahaman mereka terhadap kosakata dalam wacana berbahasa Arab yang telah dipelajari.

Hasil yang diperoleh dari Tes Hasil Belajar pada Siklus 1 diketahui nilai terendah 60 , nilai tertinggi 93 , dan nilai rata-rata sebesar 78,2 . Di antara 40 orang siswa yang mengikuti tes, ada 24 orang (60\%) yang telah melampaui KKM, yaitu 75. Selebihnya sebanyak $40 \%$ siswa masih memiliki nilai di bawah KKM. Apabila persentase jumlah siswa yang belum dan sudah mencapai KKM pada Siklus 1 disajikan dalam Grafik 1 di bawah ini. 


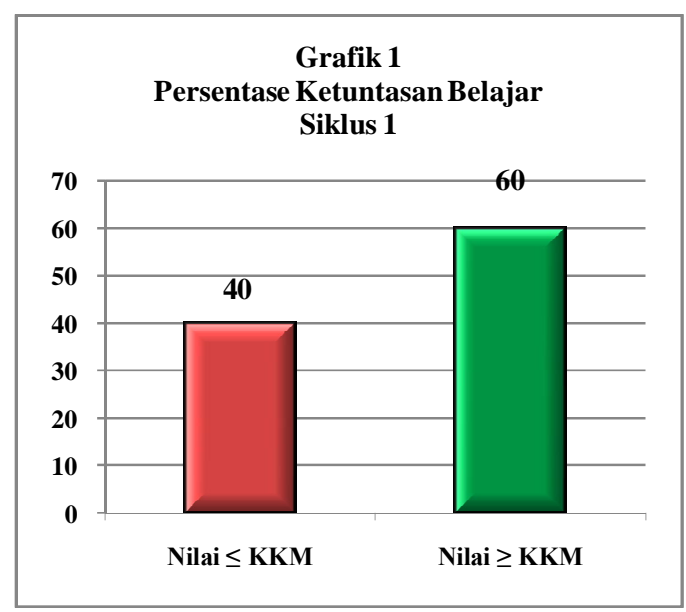

Pada pembelajaran Siklus 1, guru hanya menggunakan bahan ajar yang dibagikan kepada setiap bangku dan perangkat permainan Memilih Pasangan Kartu. Sebelum permainan dimulai tidak ada kegiatan tanya jawab secara klasikal dengan guru setelah latihan dalam kelompok. Jumlah grup ada 4, setiap grup terdiri atas 2 kelompok sehingga terjadi 4 kali permainan dalam pembelajaran. Waktu yang dialokasikan untuk tiap grup adalah 4 menit dan penghitungan waktunya kurang akurat. Tidak ada iringan musik pada saat permainan berlangsung. Hasil penelitian terlihat pada Tabel 1 di bawah ini:

\section{Tabel 1}

\section{Ringkasan Hasil Penelitian Siklus 1}

\begin{tabular}{|c|c|c|}
\hline No. & Hasil Penelitian & Jumlah \\
\hline 1. & Siswa aktif & 31 orang \\
\hline 2. & Nilai Rata-rata & 78,2 \\
\hline 3. & $\begin{array}{c}\text { Persentase } \\
\text { Ketuntasan }\end{array}$ & $60 \%$ \\
\hline
\end{tabular}

Interpretasi terhadap hasil penelitian di atas adalah bahwa pembelajaran masih perlu diperbaiki dan ditingkatkan. Perlu adanya media pembelajaran yang digunakan guru di depan kelas untuk menjelaskan makna kosakata sebelum pembagian bahan ajar kepada setiap bangku. Kegiatan tanya jawab dengan guru sebelum permainan perlu dilakukan. Jumlah grup harus disederhanakan untuk meningkatkan keterlibatan siswa dan efisiensi waktu. Alokasi waktu permainan untuk tiap grup masih kurang dan cara penghitungan harus akurat. Suasana ketegangan selama permainan harus diubah menjadi suasana yang lebih santai dan menyenangkan.

Setelah penggunaan permainan dalam pembelajaran yang dilakukan pada Siklus 1, peneliti dan kolaborator kemudian melakukan refleksi mengenai perubahan yang 
terjadi pada siswa, suasana kelas, dan guru akibat tindakan tersebut.

Perubahan yang terjadi pada siswa adalah timbulnya semangat dan motivasi mereka dalam belajar karena mereka diberi tahu sejak awal bahwa akan ada permainan Memilih Pasangan Kartu setelah penyajian materi oleh guru yang akan dilanjutkan dengan tes akhir. Mereka lebih fokus dan serius dalam mengikuti presentasi materi oleh guru.

Pada saat pembagian kelompok dengan cara berhitung mulai dari arah kiri depan sampai paling belakang, tampak jelas bermacam-macam ekspresi siswa; ada yang muram karena kecewa, ada yang ceria karena bergabung dengan temannya yang dianggap pandai, bahkan ada yang histeris kegirangan karena sekelompok dengan teman yang cocok. Para siswa tidak kelihatan bosan dan ngantuk, dan mereka dapat bergerak leluasa, tidak hanya duduk di bangku, mendengarkan dan menulis pelajaran. Sesaat sebelum permainan dimulai, kelompok yang telah terbentuk melakukan latihan dalam kelompok.

Ketika permainan berlangsung, suasana kelas cukup ramai. Ada yang memberi semangat pada dua kelompok yang sedang bertanding, ada yang sibuk menghafal dengan kelompoknya, ada juga yang membaca buku. Hal yang paling menonjol dari aktivitas siswa adalah interaksi antarsiswa dalam kelompok yang sedang melakukan permainan. Kelompok yang sedang melakukan permainan tampak cemas dan sedikit tegang mengingat waktu yang disediakan sangat terbatas yakni empat menit. Akan tetapi di tengah ketagangan itu mereka begitu bersemangat untuk mengumpulkan poin sebanyak-banyaknya. Ketegangan dan keceriaan mereka saat melakukan permainan tampak pada Gambar 1 dan 2.

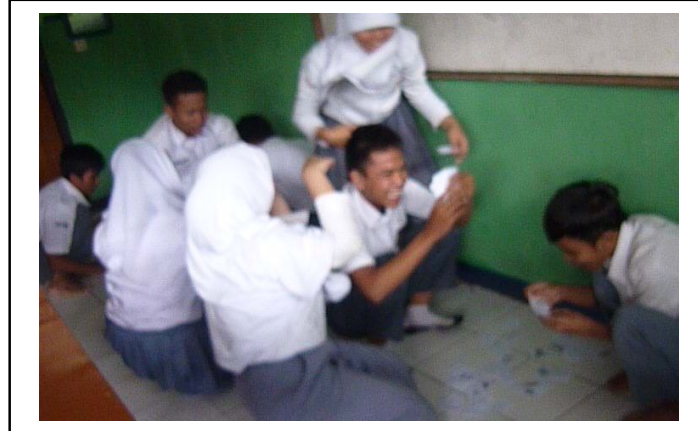

Gambar 1

Keceriaan siswa saat melakukan permainan

Guru yang biasanya lebih banyak memberikan ceramah dan menjadi sumber utama materi pelajaran dari awal sampai akhir pembelajaran, kini merasakan suasana yang berbeda. Dalam

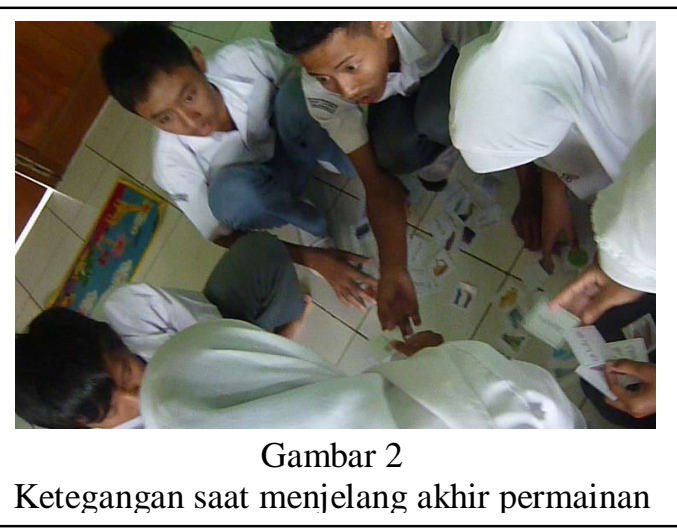

kegiatan ini guru juga berperan dalam mengarahkan juri dalam menjalankan tugasnya dan memantau jalannya pertandingan seperti yang tampak pada gambar 3. 


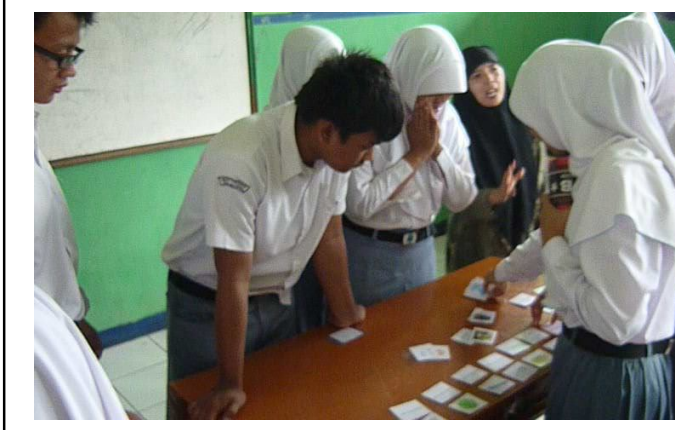

Gambar 3

Guru memberi arahan kepada juri

Kegembiraan yang terpancar dari wajah siswa, mendorong guru untuk menyiapkan media yang menarik untuk pembelajaran berikutnya. Beberapa siswa yang dengan sengaja mendekati meja guru untuk mengatakan bahwa pembelajaran hari itu seru juga menambah semangat untuk terus menyajikan pembelajaran yang menyenangkan.

Meskipun pelaksanaan permainan ini cukup sukses, pada Siklus 1 peneliti dan observer menemukan hal-hal yang perlu diperbaiki. Ada beberapa orang di antara mereka yang kurang perhatian pada kelompok yang sedang berlaga. Padahal dengan memperhatikan jalannya pertandingan kelompok lain, secara tidak langsung mereka akan mendapatkan penguatan ingatan dan pemahaman. Selain itu, kadang-

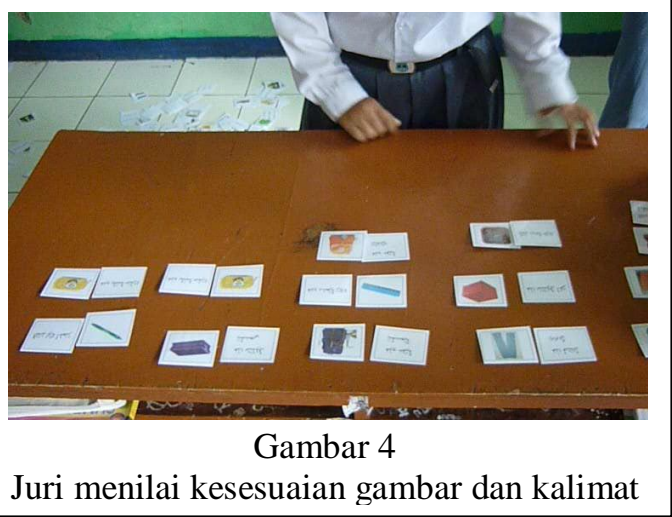

kadang keramaian siswa yang tidak sedang bertanding ini pun agak sulit dikendalikan sehingga perlu alat bantu untuk memfokuskan perhatian mereka.

Teknik pembagian kartu harus diperbaiki pada siklus berikutnya. Pada Siklus I guru meminta kedua kelompok yang sedang bertanding untuk memilih kartu di lokasi yang sama. Tenik pembagian kartu seperti ini sebenarnya membuat permainan menjadi seru, akan tetapi memberi peluang kepada mereka untuk kontak fisik berebut kartu yang dapat saja menjurus pada kekerasan. Tidak jarang juga mereka melakukan kecurangan dengan sengaja memonopoli kartu yang belum dipasangkan agar tidak diambil oleh kelompok lawan. Suasana rebutan kartu tampak pada gambar 5 dan 6 .

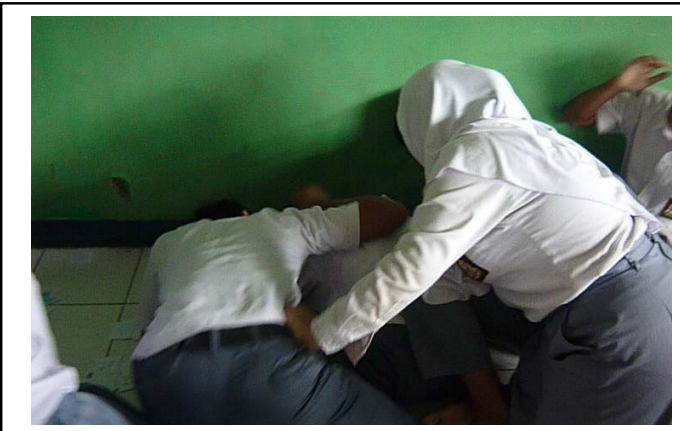

Gambar 5

Suasana agak kacau karena berebut kartu

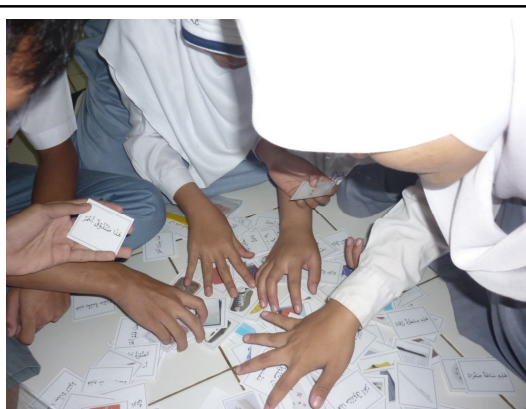

Gambar 6

Suasana saat memilih kartu 

Dari sisi waktu, pada Siklus 1 benar-benar sangat sempit karena permainan dibagi dalam empat grup. Akibat lamanya waktu yang digunakan untuk empat kali permainan, siswa tidak mendapatkan waktu yang cukup untuk mengerjakan soal pada tes hasil belajar di akhir pembelajaran pada pertemuan tersebut sehingga perolehan nilainya belum optimal.

Latar pertandingan pada Siklus 1 yang harus perbaiki adalah sepi atau suara keributan. Dua hal ini harus diatasi dengan media yang dapat lebih menghangatkan suasana permainan menjadi lebih meriah misalnya musik instrumentalia.

Kurangnya perhatian kelompok yang tidak sedang bertanding pada kelompok yang sedang bertanding akan diatasi dengan melibatkan mereka secara maksimal pada waktu yang bersamaan. Permainan akan dibagi dalam dua grup yakni A dan B. Setiap grup terdiri atas empat kelompok. Pada saat grup A bermain, semua anggota grup B menjadi juri. Jadi tiap kelompok yang bermain diawasi oleh kelompok juri. Dengan demikian siswa yang tidak sedang bertanding tidak menganggur tetapi berperan sebagai juri yang tugasnya telah disampaikan oleh guru. Di samping dapat melibatkan siswa lebih banyak, penyederhanaan jumlah grup ini juga dapat membuat waktu lebih efisien.

Adanya peluang kontak fisik dan kecurangan pada Siklus 1 dapat diatasi dengan perubahan teknik pembagian paket kartu. Paket kartu akan dibagikan kepada setiap kelompok tanpa harus berebut dengan kelompok lain. Mereka akan lebih fokus pada memahami teks pada kartu kalimat dan memilih gambar pada kartu gambar yang sesuai dalam waktu yang ditentukan.

Untuk lebih menghangatkan suasana, pertandingan pada Siklus 2 akan diiringi dengan musik latar yang sesuai.

Pembelajaran pada Siklus 2 merupakan perbaikan dari hasil refleksi terhadap proses pembelajaran pada Siklus 1. Kompetensi yang akan dicapai adalah memahami wacana sederhana bahasa Arab dengan topik Di dalam Kelas (في الفصل) yang mengandung struktur Warna (الألو ان).

Pada Siklus 2 permainan dalam pembelajaran dibagi dalam dua grup, jadi siswa dapat lebih tenang dalam memilih pasangan kartu jika dibandingkan dengan sebelumnya. Penyederhanaan jumlah grup pada Siklus 2 ini membuat waktu menjadi lebih efisien dan menjadikan suasana permainan lebih teratur. Keterlibatan kelompok yang tidak sedang bertanding pun lebih banyak karena pada saat yang lain bermain, mau tidak mau kelompok yang tidak sedang bermain harus menjadi juri dengan tugas utama menghitung jumlah skor perolehan kelompok yang diawasinya. Suasana pada Siklus 2 dapat dilihat pada gambar 7 dan 8 .
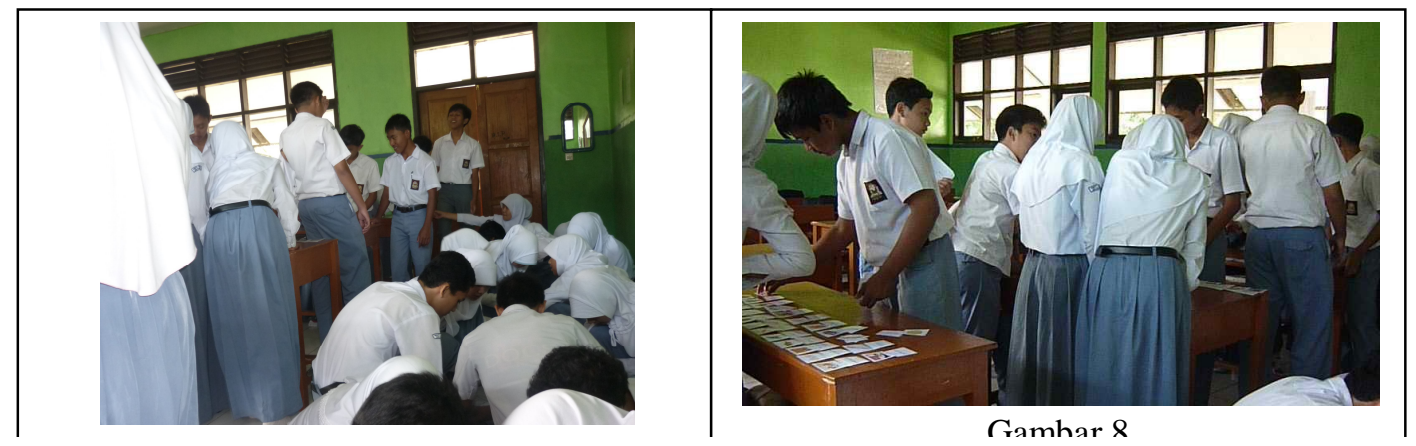

Penghitungan waktu pada Siklus 2 tidak lagi dilakukan secara manual melainkan dengan menggunakan aplikasi bel otomatis karya programmer Wawan Supriadi agar lebih akurat. Suara penandanya menggunakan suara terompet lucu. Untuk keperluan ini guru menyiapkan speaker aktif yang dihubungkan dengan laptop sehingga meskipun ukurannya kecil suaranya dapat terdengar dengan jelas. Waktu yang disediakan untuk setiap permainan juga bertambah dari yang semula hanya 4 menit, pada Siklus 2 ini menjadi 6 menit. Ini bertujuan agar mereka lebih dapat menguasai kosakata yang ada pada kalimat dalam kartu tersebut.

Hal lain yang berbeda adalah guru memutarkan musik instrumentalia sebagai pengiring selama permainan tiap grup berlangsung. Musik yang diputar pada sesi pertama (Grup A) saat itu adalah Track 01 Instrumentalia Piano karya Richard Clayderman yang dilanjutkan dengan Track 01 Musik Klasik Karya Antonio Vivaldi sampai genap 6 menit. Sedangkan pada sesi kedua (Grup B) musik yang diputar adalah Instrumentalia saxophone karya Dave Koz.

Hasil yang diperoleh dari Tes Hasil Belajar pada Siklus 2 diketahui nilai terendah 67 , nilai tertinggi 100 , dan nilai rata-rata sebesar 82,4 . Di antara 40 orang siswa yang mengikuti tes, sudah ada 30 orang (75\%) yang telah mencapai KKM. Selebihnya sebanyak 25\% siswa masih dalam kategori Belum Tuntas karena memiliki nilai di bawah KKM. Apabila persentase jumlah siswa yang belum dan sudah mencapai KKM pada Siklus 2 disajikan dalam Grafik batang, tampak seperti pada Grafik 2 di bawah ini.

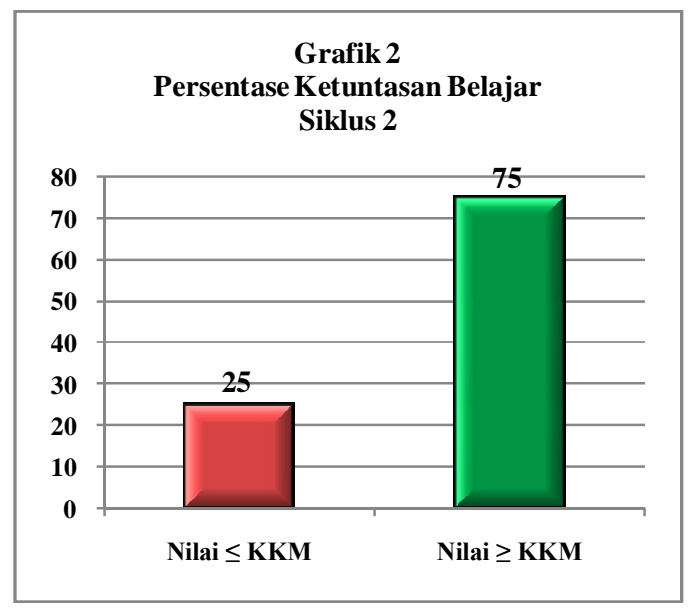

Pada pembelajaran Siklus 2, guru sudah menggunakan media kartu berukuran agak besar yang dimanfaatkan untuk penjelasan materi di depan kelas sebelum pembagian bahan ajar kepada setiap bangku. Sebelum permainan dimulai dilakukan kegiatan tanya jawab secara klasikal antara siswa dengan guru. Jumlah grup sudah disederhanakan menjadi 2 dan tiap grup terdiri atas 4 kelompok sehingga hanya perlu 2 kali permainan dalam pembelajaran. Waktu yang dialokasikan untuk tiap grup sudah bertambah menjadi 6 
menit dan penghitungan waktunya sudah dilakukan secara otomatis. Ada iringan musik pada saat permainan berlangsung untuk mencairkan suasana. Hasil penelitian dapat dilihat pada Tabel 2 di bawah ini:

\begin{tabular}{|c|c|c|}
\hline \multicolumn{3}{|c|}{$\begin{array}{c}\text { Tabel } 2 \\
\text { Ringkasan Hasil Penelitian Siklus } 2\end{array}$} \\
\hline No. & Hasil Penelitian & Jumlah \\
\hline 1. & Siswa aktif & 39 orang \\
\hline 2. & Nilai Rata-rata & 82,4 \\
\hline 3. & $\begin{array}{l}\text { Persentase } \\
\text { Ketuntasan }\end{array}$ & $75 \%$ \\
\hline
\end{tabular}

Interpretasi terhadap hasil penelitian di atas adalah bahwa pada Siklus 2 pembelajaran sudah menunjukkan peningkatan hasil belajar dan peningkatan aktivitas siswa dalam pembelajaran.

Setelah pelaksanaan dan observasi Siklus 2 dilalui, peneliti dan kolaborator melakukan refleksi mengenai perubahan yang terjadi pada siswa, suasana kelas, dan guru akibat penggunaan Permainan Memasangkan Kartu pada pembelajaran. Perubahan yang terjadi pada siswa adalah terjaganya intensitas motivasi mereka dalam belajar.

Sikap dan perilaku mereka dalam belajar tidak menurun meskipun permainan itu terus dilakukan dalam dua siklus. Mereka mengikuti pembelajaran dengan fokus dan serius. Kelompok yang mendapatkan skor tinggi dalam permainan tampak cukup percaya diri dan bangga dengan perolehannya walaupun mereka tahu bahwa skor tersebut tidak masuk dalam daftar nilai guru. Kelompok yang perolehan skornya paling rendah semakin penasaran dan meminta guru untuk melakukan permainan ini kembali pada waktu yang akan datang dengan tekad memperbaiki perolehan skor.

Latihan dalam kelompok yang dilakukan sebelum permainan dimulai, semakin dirasakan penting oleh mereka demi memperoleh skor tertinggi dalam permainan.

Suasana kelas pada Siklus 2 menjadi lebih bersahabat dengan alunan musik pengiring permainan. Siswa yang tidak sedang bermain tampak mengikuti irama musik dengan anggukan kepala dan gerakan jari tangannya. Rupanya siswa terkesan dengan adanya musik dalam pembelajaran ini sehingga di antara mereka ada yang meminta untuk meng-copy file musik tersebut. Guru semakin tertantang untuk selalu menyajikan pembelajaran yang menyenangkan bagi siswanya. Dengan penggunaan permainan ini dalam pembelajaran guru menjadi lebih percaya bahwa kualitas proses dan hasil belajar akan meningkat.

Penggunaan permainan pada Siklus 2 cukup berhasil meningkatkan aktivitas dan hasil belajar siswa. Ketuntasan belajar sebesar $75 \%$ merupakan pencapaian yang membuktikan efektivitas pembelajaran. 
Data hasil tes pada Siklus 1 dan 2 adalah data yang digunakan untuk mengukur peningkatan kemampuan siswa dalam memahami waacana berbahasa Arab melalui penggunaan
Memasangkan Kartu dalam pembelajaran Bahasa Arab.

Persentase ketuntasan belajar siswa pada Siklus 1 dan Siklus 2 dapat dilihat pada Tabel 3 dan di bawah ini.

Tabel 3

Persentase Ketuntasan Belajar pada Siklus 1 dan Siklus 2

\begin{tabular}{|c|c|c|c|c|}
\hline \multirow{2}{*}{ Nilai } & \multicolumn{2}{|c|}{ Siklus 1 } & \multicolumn{2}{c|}{ Siklus 2 } \\
\cline { 2 - 5 } & Jumlah & $\%$ & Jumlah & $\%$ \\
\hline $\begin{array}{c}\text { Nilai } \leq \text { KKM } \\
(75)\end{array}$ & 16 & 40 & 24 & 60 \\
\hline $\begin{array}{c}\text { Nilai } \geq \text { KKM } \\
(75)\end{array}$ & 10 & 25 & 30 & 75 \\
\hline $\begin{array}{c}\text { Nilai Rata- } \\
\text { rata }\end{array}$ & \multicolumn{2}{|c|}{78,2} & \multicolumn{2}{|c|}{82,4} \\
\hline
\end{tabular}

Dari Tabel di atas, dapat kita lihat hasil tindakan dari tiap siklus. Pada Siklus I persentase siswa yang mendapat nilai $\leq$ KKM (75) adalah sebesar $40 \%$ dan pada pertemuan kedua sudah berkurang menjadi $25 \%$. Perolehan Nilai Rata-rata pada
Siklus 1 adalah sebesar 78,2 dan mengalami peningkatan pada Siklus 2 menjadi 82,4.

Berikut ini adalah peningkatan perolehan nilai hasil belajar tiap-tiap Siklus yang disajikan dalam Grafik 3.

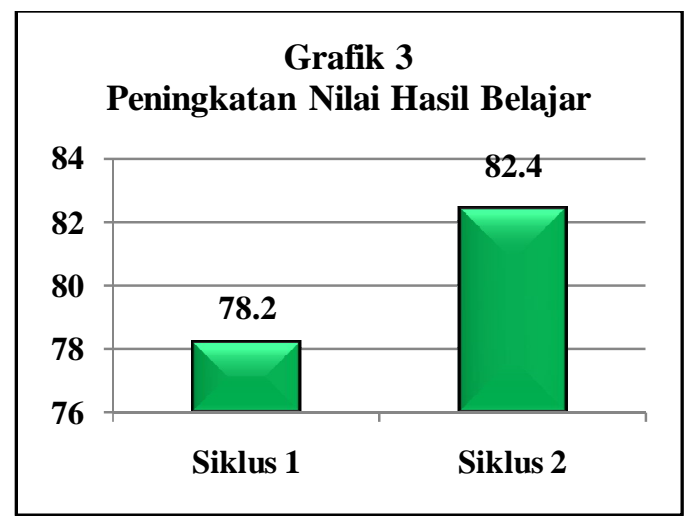

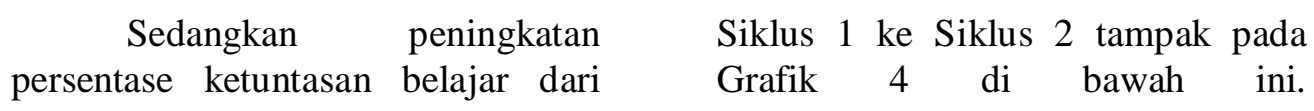




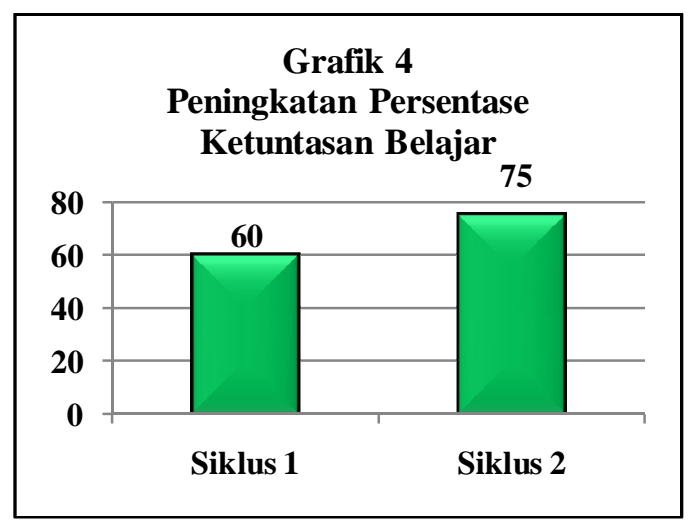

Aktivitas siswa dalam pembelajaran dapat ditinjau dari banyaknya siswa yang terlibat aktif saat Kegiatan Inti dalam KBM. Hasil penelitian menunjukkan pada Siklus 1 jumlah siswa yang konsisten terlibat aktif dalam pembelajaran adalah sebanyak 31 orang. Hal ini berbeda keadaannya dengan yang terjadi pada Siklus 2 karena dari 40 orang siswa yang ada di kelas tersebut hampir seluruh siswa terlibat aktif dalam proses pembelajaran. Pada Siklus 2 hanya ditemukan 1 orang siswa yang berkali-kali memandang ke luar kelas, terpengaruh oleh suasana di luar kelas, selebihnya mengikuti kegiatan pembelajaran dengan keterlibatan penuh.

\section{SIMPULAN}

Merujuk pada hasil penelitian ini, dapat penulis simpulkan bahwa langkah-langkah penggunaan Permainan Memasangkan Kartu dalam pembelajaran Bahasa Arab di Kelas X-3 SMAN 1 Cicurug adalah dimulai dengan apersepsi, pemberian motivasi, presentasi kelas, pembagian kelompok, latihan dalam kelompok, pelaksanaan permainan, pemberian penghargaan kepada kelompok, pelaksanaan tes, dan refleksi. Dengan pengelolaan yang baik, penggunaan permainan ini berkontribusi positif terhadap peningkatan aktivitas siswa sehingga mereka terlibat penuh dalam belajar dan mampu meningkatkan hasil belajar siswa.

\section{UCAPAN TERIMA KASIH}

Peneliti mengucapkan terima kasih kepada semua pihak yang telah membantu penulisan artikel ini. Ucapan terima kasih juga disampaikan kepada Jurnal Bahasa \& Sastra atas dimuatnya artikel ini.

\section{PUSTAKA RUJUKAN}

Depdiknas. 2006. Lampiran Permendiknas Nomor 22 Tahun 2006 tentang Standar Isi. Jakarta: Balitbang Puskur.

Hernowo. 2005. Menjadi Guru yang Mau dan Mampu Mengajar Secara Menyenangkan. Bandung: MLC.

Mujib, Fathul \& Nailur Rahmawati. 2011. Metode Permainanpermainan Edukatif dalam Belajar Bahasa Arab. Jogjakarta: Diva Press.

Mulyadi, Yadi. 2012. Implementasi approche globale des textes écrits dalam pembelajaran membaca teks: laporan penelitian. Bandung: Tidak diterbitkan. 
bahasa \& sastra, Vol. 13, No.1, April 2013

Sadiman, Arif S. 2011. Media Pendidikan: Pengertian, Pengembangan, dan Pemanfaatannya. Jakarta: Rajagrafindo Persada.

Shiny, Mahmud Isma'il \& Nashif Mushthafa Abdul Aziz. 1983. Mursyid al-Mu'allim fi Tadriis al-'Arabiyyah li Ghair alNaathiqiina biha: tathbiiqaat 'Amaliyat li Taqdiim al-Duruus wa Ijraai al-Tadriibaat. Riyadh: Daar al-Ulum.
Sudjana, N. \& Rivai, A. 1992. Media Pengajaran. Bandung: CV Sinar Baru Bandung.

Suyatno. 2009. Menjelajah pembelajaran Inovatif. Sidoarjo: Masmedia Buana Pustaka.

Yosodipuro, Arif.2013. Siswa senang, guru gemilang; Strategi mengajar yang menyenangkan dan mendidik dengan cerdik. Jakarta: Gramedia Pustaka Utama 